\title{
KETERAMPILAN MEMBACA DAN TEKNIK PENGEMBANGANNYA DALAM PEMBELAJARAN BAHASA ARAB
}

Anwar Abd. Rahman

Email: anwarabdrahman@gmail.com

Fakultas Adab dan Humaniora UIN Alauddin Makassar
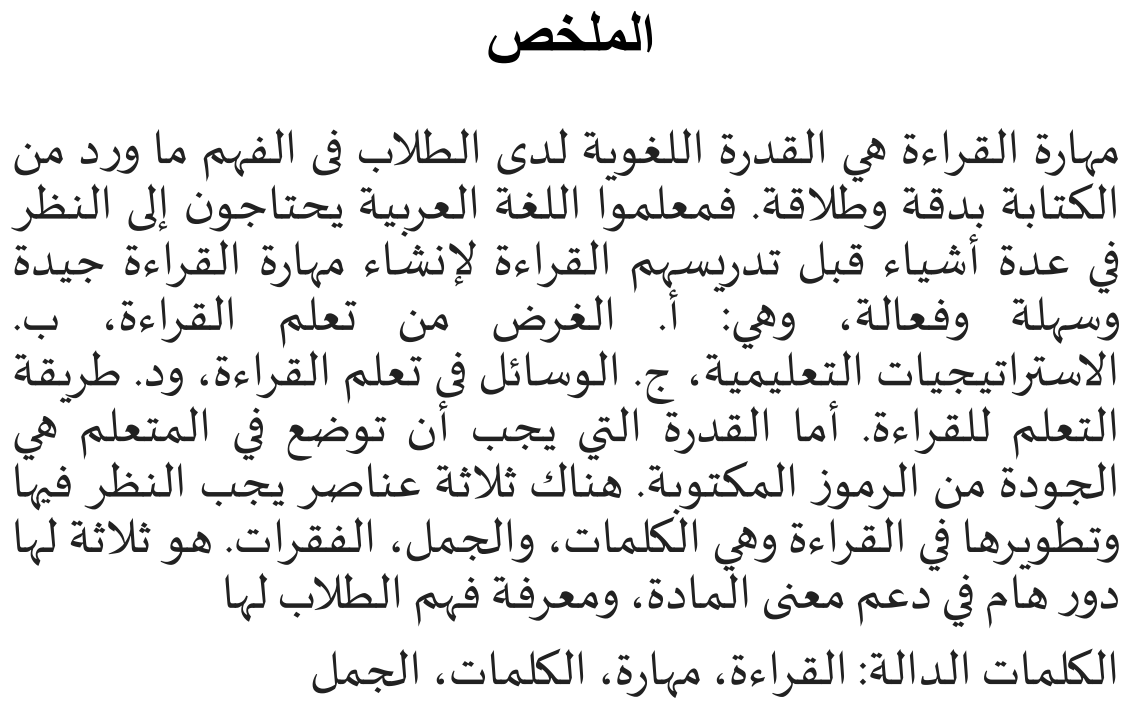

\begin{abstract}
Abstrak
Kemahiran (keterampilan) membaca adalah suatu kemampuan berbahasa yang dimiliki seseorang dalam melihat dan memahami apa makna yang terkandung dalam sebuah tulisan dengan terampil, tepat, dan fasih. Hal-hal yang perlu diperhatikan oleh seorang guru bahasa Arab dalam pembelajaran Qirā ah untuk menciptakan maharah al-qirā'ah dengan baik, mudah dan tepat sasaran, adalah: a. Tujuan pembelajaran qirā'ah, b. Strategi pembelajaran qirā 'ah, c. Media pembelajaran qirā'ah, dan d. Metode pembelajaran qirā'ah. Kemampuan yang harus dikembangkan dalam diri pelajar adalah kemahiran mengenai simbol-simbol tertulis. Ada tiga unsur yang harus diperhatikan dan dikembangkan dalam pelajaran qira'ah yaitu kata, kalimat, paragrap. Ketiganya berperan sangat penting dalam mendukung makna suatu bahan bacan, dan untuk mengetahui pemahaman murid tentang sesuatu bacaan
\end{abstract}

Kata Kunci: Bacaan, keterampilan, kata, kalimat 


\section{A. Latar Belakang Masalah}

Bahasa Arab sebagai bahasa al-Qur'ān (Agama) sedari dulu menjadi bahasa ilmu pengetahuan ${ }^{1}$. dan teknologi. Posisi bahasa Arab di tingkat Internasional sudah disejajarkan dengan bahasa-bahasa resmi yang digunakan di $\mathrm{PBB}^{2}$. Kongkritnya, kini dunia Internasional telah mengakui bahasa Arab sebagai bahasa Internasional yang sejajar dengan bahasa Inggris, Perancis, Rusia, Cina dan Spanyol. ${ }^{3}$ Sebuah pengakuan yang tidaklah berlebihan, oleh karena peranan bahasa Arab sedari dulu hingga kini tidak dapat dinafikan sebagai bahasa Agama dan bahasa Ilmu Pengetahuan.dan teknologi.

Orang berbahasa pada hakekatnya berkomunikasi dengan orang lain untuk menyampaikan pesan di antara mereka. Dan komunikasi yang efektif adalah komunikasi yang terjadi antara komunikator dan komunikan yang mana pesan yang ingin disampaikan oleh komunikator kepada komunikan melalui media dapat diterima dan dipahami dengan baik. Hanya saja, dalam praktek pengajaran bahasa Arab komunikasi sering tidak memperoleh perhatian sehingga yang diajarkan hanyalah pengetahuan tentang berbahasa dan bukan keterampilan bagaimana agar murid bisa berbahasa secara langsung dan mampu berkomunikasi dengan orang lain. Akibatnya, tidak jarang didapati fenomena yang ironis. Mengingat penguasaan bahasa Arab seseorang adakalanya terbatas pada penguasaan terhadap kaedah-kaedah bahasa Arab (nahwu sharaf) tanpa mampu mengaplikasikannya dalam praktek komunikasi atau justru sebaliknya. Meski demikian, tidaklah berarti bahwa penguasaan kaidah (nahwu sharaf) dalam bahasa Arab tidaklah urgen sehingga serta merta mengenyampingkannya. Tidak dapat dipungkiri, bahwasanya antara bahasa Arab dengan materi nahwu sharaf memang tidak dapat terpisahkan satu sama lain.

Ilmu nahwu dan sharaf adalah ilmu dasar yang bersifat strategis. Mengingat, menguasai keduanya baik secara teori maupun praktek, sedikit banyaknya akan memengaruhi kemampuan membaca bahasa Arab dengan baik dan memahami bahasa Arab dengan tepat. ${ }^{4}$ Namun tetap saja, idealnya penguasaan bahasa Arab mencakup empat aspek keterampilan berbahasa.

\section{End Notes:}

${ }^{1}$ Peranan bahasa Arab dalam ilmu pengetahuan dapat dibuktikan dari kenyataan sejarah yaitu pada masa kekhalifahan Abbasiyah yang terkenal dengan abad terjemah). Lebih lanjut baca: Imam Makruf, Strategi Pembelajaran Bahasa Arab Aktif(Cet. I; Semarang: Need`s Press), h. 9.

${ }^{2}$ Di Perserikatan Bangsa-Bangsa (PBB) bahasa Arab telah digunakan sejak tahun 1973. Ibid., h. 11 .

${ }^{3}$ Lihat, Azhar Arsyad, Bahasa Arab dan Metode Pengajarannya : Beberapa Pokok Pikiran (Cet. II ; Jakarta : Pustaka Pelajar, 2004), h. 11. Lihat pula: Abdul Mu`in, Analisis Kontrastif Bahasa Arab dan Bahasa Indonesia (Telaah terhadap Fonetik dan Morfologi) (Jakarta: Pustaka Al Husna Baru, 2004), h.38.

${ }^{4}$ AH. Akrom Fahmi, Ilmu Nahwu dan Sharaf (Tata Bahasa Arab) Praktis dan Aplikatif (Cet. III ; Jakarta : PT. Raja Grafindo, 2003), h. xi. 
Sebagaimana lazimnya bahasa-bahasa yang lain, bahasa Arab memiliki 4 (empat) aspek keterampilan berbahasa (mahärah al-lughah) yang dikenal pula dengan istilah funuun al-lughah (seni-seni bahasa). Substansinya, aspek paling mendasar dari bahasa adalah alat komunikasi dan keterampilan adalah bagian paling mendasar ketika menggunakan bahasa. ${ }^{5}$ Keempat mahārah tersebut antara lain sebagai berikut: mahārah al-istima', marahārah al-kalam, mahārah al-qirā'ah, dan mahārah alkitabah..

Membaca merupakan keterampilan bahasa yang tidak kalah pentingnya dibanding keterampilan bahasa yang lainnya. Kalau dalam pelajaran menyimak, siswa memiliki banyak keterbatasan baik dari sisi waktu berlatih, minimnya bahan simakan, dan kurang terpenuhinya sarana yang dibutuhkan. Dalam pelajaran berbicara siswa memiliki keterbatasan baik dari sisi kesempatan berbicara, lawan bicara, dan lain sebagainya.

Membaca merupakan pelajaran yang paling banyak peluang untuk dikembangkan. Di samping banyak tersedia bahan bacaan dalam berbagai bidang ilmu, kegiatan membaca juga bisa dilakukan kapan saja dan dimana saja. Oleh karena itu membaca bisa dijadikan salah satu fokus orientasi program pembelajaran bahasa Asing, termasuk bahasa Arab.

Olehnya itu, sehubungan dengan hal tersebut di atas, maka penulis akan membahas mengenai mahārah al-qirā ${ }^{\prime}$ hh dengan harapan dapat memberi input bagi para rekan-rekan pengajar dalam menerapkan teknik pengajaran al-qirā $a h$ dan menerapkan teknik pengembangan mahārah al-qirā $a h$ menuju pembelajaran bahasa Arab yang lebih mencerahkan ke depan. adalah:

Adapun rumusan masalah yang akan dikupas sepanjang pembahasan ini

1. Bagaimana pengertian mahārah al-qirā'ah?

2. Hal-hal apa jasa yang perlu diperhatikan dan dipertimbangkan guru bahasa Arab dalam pembelajaran al-qirā'ah?

3. Bagaimana Teknik mengembangkan mahārah al-qirā'ah?

\section{B. Pengertian Mahārah al-Qirā’ah}

Sebagaimana telah diungkapkan sebelumnya, bahwasanya mahārah al-qirā 'ah adalah salah satu dari keempat keterampilan berbahasa. Berikut akan dijelaskan apa sebenarnya pengertian istilah mahārah al-qirā'ah demikian pula aspek-aspek yang terkandung di dalamnya.

Secara etimologi kata mahārah al-qirā'ah berasal dari bahasa Arab dari kata mahārah ( مسرة ), merupakan bentuk masdar dari مهر - يمهر yang berarti pandai

\footnotetext{
${ }^{5}$ Imam Makruf, Strategi Pembelajaran Bahasa Arab Aktif (Cet. I; Semarang: Need`s Press), h.
} 18. 
atau mahir.6 Adapun kata al- qirā’ah ( قرأ - bentuk masdar dari kata يقرأ yang artinya membaca. ${ }^{7}$

Secara terminologi kata mahārah adalah kemahiran atau keterampilan yang harus dikembangkan dalam pembelajaran bahasa. ${ }^{8}$ Adapun al-qiro'ah berasal dari akar kata qoro'a-yaqro'u, qiro'atan yang artinya membaca, bacaan. Secara bahasa kata ini berasal dari ayat pertama dari wahyu al-Qur'ān, yakni “iqro”. Kata "iqro" dalam ayat tersebut adalah "fiil amr" mengandung arti perintah untuk membaca. Perintah iqro' ini dilanjutkan dengan kalimat berikutnya yakni bismirobbikalladzi kholaq, kholaqol insana min alaq. Yakni membaca dengan dasar atau kerangka "ismi rabb" (Allah sebagai Rabb). Makna iqro'/qiro'ah dalam ayat tersebut bukan sebatas harfiah yakni membaca suatu tulisan (saja), tetapi suatu perintah untuk membaca, meneliti, dan memahami. Sedangkan obyek yang harus dibaca adalah tentang manusia sebagai makhluk dan Allah sebagai kholiq (rabb). Jadi, perintah qiro'āh menurut ayat tersebut mengandung makna proses membaca, meneliti (mengkaji) dan memahami (mengenal) segalas sesuatu tanpa batas. ${ }^{9}$

Menurut Finonchiaro sebagaimana dikutip Henry membaca adalah "bringing meaning to and getting meaning from printed or written material" (memetik serta memahami arti atau makna yang terkandung di dalam bahan tertulis) Tujuannya adalah untuk mencari serta memperoleh informasi, mencakup isi, memahami makna bacaan. ${ }^{10}$ Senada dengan itu, Ahmad Izzan mendefinisikan membaca sebagai melihat dan memahami isi dari apa yang tertulis dengan melisankan atau di dalam hati dan mengeja atau melafalkan apa yang tertulis. ${ }^{11}$

Dari beberapa definisi sehubungan dengan Mahārah al-qirā'ah yang telah pemakalah paparkan di atas, dapatlah dipahami bahwasanya yang dimaksud dengan kemahiran (keterampilan) membaca dalam makalah ini adalah suatu kemampuan berbahasa yang dimiliki seseorang dalam melihat dan memahami apa makna yang terkandung dalam sebuah tulisan dengan terampil, tepat dan fasih. Sehingga pesan apa yang ingin disampaikan penulis melalui tulisannya dapat ditangkap dan dipahami maknanya oleh si pembaca dengan baik dan tepat.

\section{Hal-hal yang Perlu Diperhatikan dan Dipertimbangkan Guru Bahasa Arab dalam Pembelajaran Qirā'ah}

${ }^{6}$ Ahmad Warson Munawwir, Al-Munawwir:Kamus Arab-Indonesia (Surabaya: Pustaka Progresif, 1997), h. 1460.

${ }^{7}$ Ibid., h. 1184.

${ }^{8}$ Mahmud Faraj Abd Hafizh dkk, Muzakkirat al-Dirasah al-Tarbawiyah (t.c; t.tp: 1412 H), h. 101.

${ }^{9}$ Syaiful Gala, Konsep dan Makna Pembelajaran ( Bandung: Alfabeta, 2005), h. 134.

${ }^{10}$ Henry Guntur Tarigan, Membaca ; Sebagai Suatu Keterampilan Berbahasa, Ed, Revisi (Cet. I; Bandung: Angkasa Bandung, 2008), h. 7-9.

${ }^{11}$ Ahmad Izzan, Metodologi Pembelajaran Bahasa Arab (Cet. I; Bandung: Humaniora, 2004), h. 174 . 
Telah diketahui bersama, bahwa pada dasarnya mahārah al-qirā 'ah bersumber pada pembelajaran qirā'ah itu sendiri. Artinya, pembelajaran qirāa $a h$ memegang peranan penting dan berpengaruh besar untuk membentuk keterampilan berbahasa khususnya mahārah al-qirā ah. Sehingga semakin giat dan serius seorang peserta didik dalam mengikuti pembelajaran al-qirā'ah, maka semakin besar pula peluang baginya untuk memiliki keterampilan berbahasa yang baik.

Olehnya itu, di sinilah letak peran seorang guru bahasa Arab sebagai perancang program pembelajaran bahasa Arab, pengajar bahasa Arab, fasilitator, motivator untuk pandai-pandai memanaj antara materi ajar bahasa Arab dengan metode pembelajarannya, media pembelajaran sehingga apa yang disajikan kepada peserta didik dapat mencapai apa yang menjadi tujuan pembelajaran. Demikian pula halnya dalam pembelajaran qirā'ah. Guru kembali dituntut untuk dapat selektif, gradasi, persentase dan repetisi. Menyeleksi bahan ajaran qiră $a h$ dengan baik dan tepat, secara bertahap menyajikannya kepada siswa dan tentunya berulang-ulang. Sehingga keterampilan berbahasa dalam hal ini mahārah al-qirā'ah yang menjadi tujuan pembelajaran qirā 'ah dapat tercapai secara optimal.

Sehubungan dengan hal tersebut, maka menurut hemat penulis ada beberapa hal yang perlu menjadi perhatian seorang guru bahasa Arab. Adapun hal-hal yang perlu diperhatikan oleh seorang guru bahasa Arab, dalam pembelajaran qirā $a h$ untuk menciptakan keterampilan berbahasa dalam hal ini maharah al-qirā'ah dengan baik, mudah dan tepat sasaran adalah:

1. Tujuan pembelajaran qirā’ah

2. Strategi pembelajaran qirā'ah

3. Media pembelajaran qirā $a h$

4. Metode pembelajaran qirā'ah

Keempat hal tersebut bagi penulis sangat urgen dan meskipun mudah secara teori tetapi tidak dapat dipungkiri gampang-gampang susah pada pengaplikasiannya.

\section{Tujuan Pembelajaran Membaca}

Tujuan pengajaran al-qirā ah adalah berdasar pada tujuan pengajaran bahasa Arab seperti yang dikemukakan oleh Tarigan dan Tarigan yaitu untuk menumbuhkan dan mengembangkan empat kemahiran berbahasa yaitu kemahiran menyimak, berbicara, membaca dan menulis. ${ }^{12}$ Oleh karena itu tujuan pengajaran al-qirāah adalah untuk menumbuhkan dan mengembangkan kemahiran membaca. Kemahiran membaca tersebut mencakup dua hal yaitu:

a. Mengenali huruf alphabet Arab yang sudah tersusun menjadi kata dalam rangkaian kalimat-kalimat dan mengucapkannya dengan cepat dan benar.

b. Mengerti apa yang dibaca, kalau membaca bahan-bahan bacaan berbahasa Arab. ${ }^{13}$

${ }^{12}$ Http:// Ahsan Blogdetik. Com/2008/12/28/Pemamfaatan Internet dalam Pembelajaran Bahasa Arab (25 Maret 2009).

${ }^{13}$ A. Akrom Malibary LAS. et. al., Pedoman Pengajaran Bahasa Arab pada Perguruan Tinggi Agama Islam. Jakarta: Proyek Pengembangan Sistim Pendidikan Agama Depag RI, 1976 h. 121. 
Kemahiran membaca dianggap sebagai keterampilan utama yang mengharuskan siswa untuk mengetahui dan menguasainya melalui materi tertulis, yaitu:

1) Memperoleh keterampilan dasar membaca yang tampak dalam bacaan keras (bersuara), terkait dengan pengucapan yang benar dan keindahan dalam membaca, ketepatan dalam memberi harakat dan pemberian makna.

2) Kemampuan untuk membaca dengan cepat dan tepat dan menghasilkan ide-ide umum dan pengetahuan-pengetahuan parsial dan mengetahui tujuan makna yang tertulis dan yang tidak tertulis.

3) Memperkaya perbendaharaan bahasa bagi siswa dengan cara mereka memperoleh lafaz-lafaz, susunan kalimat, dan contoh-contoh kebahasaan yang terdapat dalam teks-teks bacaan.

4) Mendapatkan manfaat dari uslub para penulis dan penyair dan mengikuti uslubnya dengan baik.

5) Meningkatkan standar kemampuan pengungkapan, baik secara lisan maupun tulisan dan mengembangkannya melalui uslub-uslub bahasa yang benar.

6) Memperluas kajian siswa melalui pengetahuan dan kebudayaan sesuai yang diperolehnya dari beberapa literature, majalah, surat kabar, dan sarana informasi dan trasformasi lainnya.

7) Menjadikan kegiatan membaca sebagai aktifitas yang menyenangkan bagi siswa untuk menyimak setiap hal yang bermanfaat dan berfaedah secara kontinyu pada waktu senggangnya.

8) Menfungsikan bacaan sebagai sarana untuk memperoleh ilmu pengetahuan dengan merujuk pada sumber-sumber, literatur pembahasan dan kajiankajian yang berbeda-beda.

9) Pembaca dapat merealisasikan suatu tujuan utama atau lebih ketika membaca untuk aktivitas yang berbeda-beda, sebagai hasil keterampilan membaca yang dimilikinya dengan cara bersungguh-sungguh dalam meresume dengan baik dalam waktu yang singkat.

10) Membantu siswa/mahasiswa mempelajari beberapa materi pelajaran yang berbeda-beda pada semua tingkatan pembelajaran. Maka bacaan itu, adalah media pengajaran pokok yang merupakan jembatan yang menghubungkan antara manusia dan alam yang mengelilinginya.

11) Memperkuat hubungan dengan kitab Allah dan Sunnah nabi-Nya, memuliakan peninggalan para pendahulunya, seperti teori, ilmu pengetahuan, bahasa dan sastra. Dan tidak lupa bahwa kata pertama yang diturunkan ke hati Rulullah yaitu firman Allah (اقرأ بإسم ربك الذي خلق) yang mendorong setiap umat untuk membaca dan menuntut ilmu pengetahuan. ${ }^{14}$ Tujuan tersebut merupakan tujuan umum atau kurikuler. Adapun tujuan instruksional sebagai penjabaran dari tujuan kurikuler tersebut adalah berdasarkan

${ }^{14}$ Nâyif Mahmud Ma'ruf, , Khasâiș al- 'Arabiyyah wa Târâiq Tadrisiha (Cet. IV; BeirutLibnan: Dâr al-Nafais, 1412 H/1991 M.), h. 88-90. 
silabus pengajaran dan tema-tema esensial yang telah ditetapkan dalam bahan ajar pada setiap tingkatan.

\section{Strategi pembelajaran Qirā'ah}

Menurut Imam Makruf, pembelajaran Qirā'ah seringkali disebut dengan pelajaram muthāla ‘h (menela`ah) meskipun ada perbedaan sedikit antara keduanya. Dimana qirā'ah sebagai pelajaran membaca, muthāla'ah lebih menekankan pada aspek analisis dan pemahaman apa yang dibaca. Dan keduanya adalah proses untuk meciptakan ketarampilan berbahasa (mahārah al-qirā'ah). Artinya, keteranpilan membaca meliputi latihan membaca dengan benar sampai dengan taraf kemampuan memahami dan menganalisis isi bacaan. ${ }^{15}$

Lebih lanjut Imam Makruf memaparkan secara gamblang strategi pembelajaran qirā ${ }^{`} a h^{16}$ sebagaimana berikut:

Strategi 1

Disebut dengan Empty Outline. Tujuannya untuk melatih kemampuan siswa dalam menuangkan isi dari yang dibaca ke dalam bentuk tabel. Isi tabel tersebut tentunya disesuaikan dengan kebutuhan atau tujuan pembelajaran. Strategi ini dapat digabungkan dengan teknik The Power of Two.

Langkah-langkahnya:

a. Pilihlah bacaan sesuai dengan topic pembahasan yang telah ditentukan.

b. Siapkan format tabel yang akan ditugaskan kepada para siswa untuk mengisinya.

c. Bagikan bacaan tersebut pada masing-masing siswa, kemudian tugaskan mereka untuk membacanya dengan seksama.

d. Mintalah para siswa untuk bergabung dua-dua dengan temansebayanya kemudian mendiskusikan hasil kerja mereka masing-masing.

e. Mintalah masing-masing siswa untuk menyampaikan (presentasi) hasil pekerjaan mereka setelah didiskusikan.

f. Berikan klafisikasi terhadap hasil kerja siswa tersebut agar tidak terjadi kesalahan.

Strategi 2

Disebut strategi analysis. Tujuannya untuk melatih siswa dalam memahami isi bacaan dengan cara menemukan ide utama dan ide-ide pendukungnya. Juga melatih ketajaman analisis terhadap isi bacaan serta menemukan alur piker dari penulisnya.

Langkah-langkah:

a. Bagikan teks/bacaan kepada masing-masing siswa.

b. Mintalah semua siswa untuk membaca teks tersebut dengan seksama.

c. Mintalah masing-masing siswa untuk menentukan (menuliskan) ide utama dan pendukung secara individu.

${ }^{15}$ Imam Makruf, Strategi Pembelajaran Bahasa Arab Aktif (Cet. I; Semarang: 2009), h. 108109.

${ }^{16}$ Ibid., h. 109-114. 
d. Mintalah siswa untuk berkelompok dan mendiskusikan hasil masing-masing.

e. Mintalah beberapa siswa untuk menyampaikan hasilnya (persentasi) di depan kelas mewakili kelompoknya.

f. Berikan kesempatan kepada kelompok lain untuk memberikan komentar atau pertanyaan.

g. Berikan klasifikasi terhadap hasil kerja siswa tersebut agar pemahaman terhadap bacaan semakin baik.

\section{Strategi 3}

Disebut Snow balling. Hampir sama dengan The Power of Two atau small group presentation. Hanya saja prosesnya beda, karena strategi ini berjalan melalui beberapa tahap tergantung banyak sedikitnya jumlah siswa yang ada. Efektif digunakan untuk kelas dengan jumlah siswa yang besar.

Langkah-langkahnya sebagai berikut:

a. Bagikan teks kepada masing-masing siswa

b. Mintalah masing-masing siswa untuk membaca teks tersebut.

c. Mintalah masing-masing siswa untuk menentukan ide utama dan pendukung secara individu.

d. Mintalah siswa untuk berkelompok dua-dua dan mendiskusikan hasil kerja masing-masing.

e. Gabungkan setiap dua kelompok menjadi satu (menjadi empat orang) untuk mendiskusikan hasil masing-masing.

f. Gabungkan setiap dua kelompok menjadi satu (delapan orang) untuk mendiskusikan hasil masing-masing. Begitu seterusnya.

g. Mintalah siswa untuk menyampaikan (presentasi) hasilnya di depan kelas.

h. Berikan klarifikasi terhadap hasil yang telah dirumuskan siswa tersebut.

Strategi 4

Disebut Broken Square/Text. Hal tersebut untuk merangkaikan kembali bacaan yang sebelumnya telah dipotong-potong, dan bertujuan untuk melatih siswa dalam menyusun sebuah naskah tang sistematis. Serta memahami isi bacan secara global, hingga dapat menyusun kembali bacaan tersebut secara runtut.

Langkah-langkahnya:

a. Siapkan sebuah naskah cerita yang dipotong-potong menjadi beberapa bagian.

b. Bagilah siswa ke dalam beberapa kelompok kecil.

c. Berilah teks/potongan tersebut pada masing-masing kelompoknya.

d. Mintalah semua siswa membaca teks secara bergantian dalam kelompoknya masing-masing.

e. Mintalah semua siswa untuk mengurutkan potongan-potongan teks tersebut. Setelah kerja kelompok selesai, mintalah masing-masing kelompok menyampaikan (mempresentasikan) hasilnya di depan kelas.

f. Berikan kesempatan kepada kelompok lain untuk memberikan komentar atau pertanyaan.

g. Berikan klarifikasi terhadap hasil kerja kelompok tersebut sehingga terjadi kesamaan pemahaman terhadap materi yang diajarkan. 


\section{Strategi 5.}

Disebut Index Card Match. Biasanya digunakan untuk mengajarkan kata-kata atau kalimat dengan pasangannya. Juga dapat diterapkan untuk melakukan evaluasi terhadap pemahaman siswa pada isi bacaan dengan membuat kartu-kartu soal dan jawabannya.

Langkah-langkahnya:

a. Siapkan kartu berpasangan (soal dan jawabannya) lalu diacak

b. Bagikan kartu tersebut kepada semua siswa dan mintalah mereka memahami artinya

c. Mintalah semua siswa untuk mencari pasangannya masing-masing dengan tanpa bersuara.

d. Setelah menemukan pasangannya . mintalah siswa berkelompok denganpasangannya masing-masing.

e. Berikan kesempatan kepada kelompok lain untuk memberikan komentar atau pertanyaan.

f. Berikan klarifikasi terhadap hasil kerja kelompok tersebut.

\section{Media pembelajaran Qirā $\mathbf{a h}$}

Selain strategi, media memegang peran urgen dalam pembelajaran. Menurut John M Lannon sebagaimana yang dikutip oleh Azhar Arsyad bahwa urgensi media dalam pembelajarn berdasarkan beberapa alasan: (1) media dapat menarik minat siswa, (2) meningkatkan pengertian siswa, (3) memberikan data yang kuat/terpecaya, (4) memadatkan informasi dan (5) memudahkan menafsirkan data. ${ }^{17}$

Senada dengan itu, Ahmad Salim mengutarakan beberapa manfaat dari media pembelajaran yaitu: (1) memberikan pemahaman kepada siswa tentang berbagai lafadh, (2) menjadikan siswa lebih memperhatikan dan rajin belajar, (3) menambah pemahaman siswa dan menjadikannya lebih membekas, (4) membantu untuk berfikir sistematis, (5) membantu menambah kekayaan bahasa siswa. ${ }^{18}$

Oleh Imam Makruf, berikut ditawarkannya beberapa media yang dapat digunakan dalam pembelajaran qirā $a h$.

\section{a. Kartu}

Diisi dengan berbagai macam pernyataan, kalimat, atau kata-kata. Satu untuk siswa dan satu untuk guru dengan ukuran besar agar dapat diliohat oleh siswa bagian belakang. Terdiri dari kartu soal-jawab, kartu melengkapi kalimat, kartu mufradat, kartu identitas dan kartu-kartu yang ditemukan dalam kehidupan sehari-hari.

b. Laboratorium

Dilengkapi dengan berbagai bahan bacaan dengan tingkatan yang bermacammacam. Tiap tingkatan ditandai dengan warna yang berbeda, yang mudah dihafal. c. Majalah bergambar karikatur/komik

\footnotetext{
${ }^{17}$ Azhar Arsyad, Media Pembelajaran (Jakarta: PT. Raja Grafindo Persada, 2003), h. 75.

18Ahmad Salim, al-Wasāîl al-Ta`liymiyyah fi Ta liym al-Lughah (Jakarta: t.p.,1987), h. 3.
} 
Sangat bagus dan menarik terutama bagi siswa tingkat dasar. Dan media ini perlu pertimbangan apakah sesuai dengan usia siswa, apa efek negatifnya, apakah memuat kosa kata baku, dan apakah sesuai dengan kebudayaan.

d. Poster

Dibuat dengan ukuran besar, mencolok dan menarik agar dapat dlihat dari jarak jauh. Digunakan sebagai media memperjelas isi bacaan.

e. Tachitoscope

Media untuk membaca yang memungkinkan untuk diatur lamanya penayangan naskah. Naskah yang ditampilkan dapat berupa artikel atau kisah-kisah dan setelah penyangan guru bertanya kepada siswa seputar isi bacaan.

f. Reading Pacer

Dapat digunakan untuk menampilkan bacaan dari mana saja seperti buku, majalah, Koran dan sebagainya.

g. Film Bacaan

h. Overhead Projector

i. Permainan bahasa.

Meliputi menyusun kalimat (takwin al-jumal), kata kerja dan kata keterangan (al-af al wa ad-dzuruf), cerita pendek (al-qishash al-qashirah), mengenal makna kosa kata (at ta`aruf 'ala ma`na al-mufradat), kata dan definisinya (alOkalimah wa ta`rifuha), dan mentaati perintah (itha`atu al-awamir).

\section{Metode Pembelajaran Qirā `ah}

Dalam pembelajaran membaca terdapat beberapa teori dan metode yang muncul dan berkembang. Masing-masing memiliki sisi kelebihan dan kekurangannya. Diantara metode-metode tersebut oleh Muhammad Ali Al-Khuli adalah: ${ }^{19}$

\section{Metode Harfiyyah}

Guru memulai pelajaran dengan mengajarkan huruf hija'iyyah satu persatu. Murid pun lambat dalam membaca, karena siswa cenderung membaca huruf per huruf daripada membaca kesatuan kata.

\section{Metode Sautiyyah}

Dalam metode sautiyyah huruf diajarkan kepada siswa sebagai. Urutan pengajaran ini dimulai dengan mengajarkan huruf berharkat fathah seperti dan seterusnya, kemudian huruf berharkat dhammmah, selanjutnya huruf berharkat kasrah dan sukun. Setelah itu lalu beralih ke pelajaran huruf berharkat fathatani tanwan. Setelah itu lalu beralih ke pelajaran.

Diantara kelebihan metode ini adalah mengajarkan huruf dengan bunyinya bukan dengan namanya. Namun, demikian ada juga kekurangannya diantaranya bahwa metode ini terkadang menghambat kelancaran atau kecepatan membaca siswa, karena siswa terbiasa membaca huruf hijaiyyah.

\section{Metode Suku kata}

${ }^{19}$ Muhammad Ali Al-Khuli, Asalib Tadris al-Lughah al-Arabiyyah. (Riyadh: al-Mamlakah alArabiyyah al-Su'udiyyah, 1982), h. 107 
Dalam metode ini siswa terlebih dahulu belajar suku kata, kemudian mempelajari kata yang tersusun dari suku kata tersebut. Untuk mengajarkan suku kata harus didahului oleh pembelajaran huruf mad.

\section{Metode Kata}

Metode kata ini memunyai landasan psikologis yang mengasumsikan bahwa siswa mengetahui hal-hal yang umum dulu, kemudian berkembang mengetahui bagian-bagian dari yang umum itu.

Dalam mengimplementasikan metode ini, guru memulai dengan menampilkan sebuah kata disertai dengan gambar yang sesuai jika kata itu mungkin digambar, kemudian guru mengucapkan kata itu beberapa kali dan diikuti siswa. Langkah selanjutnya guru menampilkan kata tadi tanpa disertai gambar untuk dikenali dan dibaca oleh siswa. Setelah siswa mampu membaca kata tersebut, baru kemudian guru menganalisa dan mengurai huruf-huruf yang terkandung dalam kata tadi.

Metode kata ini memiliki beberapa kelebihan, yaitu:

a. Sejalan dengan landasan psikologis pengetahuan visual manusia yang dimulai dari hal-hal umum

b. Membiasakan siswa berlatih membaca cepat

c. Siswa memulai membaca satuan kata yang mempunyai arti

Metode ini mempunyai kekurangan, yaitu:

a. Terkadang siswa lebih terfokus pada gambar daripada kata yang diajarkan

b. Terkadang siswa hanya menebak dan mengira kata berdasarkan gambar, bukan membaca yang sesungguhnya.

c. Jika kata yang diajarkan bentuknya sangat mirip, siswa terkadang mengacaukannya.

\section{Metode Kalimat}

Prosedur pembelajaran membaca dengan metode ini adalah dengan cara guru pertama kali menampilkan sebuah kalimat pendek di kartu atau di papan tulis, kemudian membaca kalimat tersebut beberapa kali dan diikuti oleh siswa.

Urutan metode kalimat ini adalah dari kalimat ke kata kemudian ke huruf.

Kelebihan metode kalimat ini adalah:

a. Sejalan dengan landasan psikologis pengetahuan dimulai dari hal-hal umum menuju bagian-bagian yang kecil

b. Metode ini mengedepankan satuan kalimat atau kata yang bermakna

c. Membiasakan siswa membaca satuan yang lebih besar dan memperluas pandangan

Kelemahan dari metode ini:

Sedikit banyak menguras tenaga guru dan membutuhkan guru yang terlatih, sementara ketersediaan guru professional dalam bidang pembelajaran bahasa arab bagi orang asing sangat terbatas.

6. Metode Gabungan 
Para pengikut metode gabungan ini berpendapat bahwa setiap metode memiliki kelebihan dan pada waktu yang sama memiliki kekurangan. Maka yang terbaik adalah meramu semua metode dengan memperhatikan sisi baiknya, dan tidak terpaku kepada metode tertentu. ${ }^{20}$ Metode ini menggabungkan antara metode harfiyyah, sautiyyah, suku kata, Metode kata, metode kalimat.

\section{Teknik Mengembangkan Mahārah al-Qirā’ah}

Setelah siswa memiliki keterampilan berbahasa (Mahārah al-qirā'ah), tentu tugas guru bahasa Arab tidak hanya sampai di situ. Perlu dipikirkan lagi bagaimana cara agar keteranpilan tersebut dapat dikembangkan lebih lanjut.

Mempelajari bahasa, metode dan teknik mempunyai hubungan yang erat sekali dengan tujuan pengajaran bahasa. Oleh karena itu tujuan pengajaran suatu bahasa haruslah dirumuskan sedemikian rupa agar arah yang akan dituju tepat mengenai sasaran, yakni agar para peserta didik dapat menguasai bahasa Arab sebagaimana mendekati kefasihan penutur aslinya atau paling tidak mendekati keadaan itu. ${ }^{21}$

Dalam menetapkan suatu metode pengajaran, seorang guru/dosen menyesuaikan dengan tujuan pembelajaran yang telah dirumuskan. Setelah guru merumuskan tujuan pembelajaran, maka persoalan selanjutnya adalah memilih materi yang diikuti dengan penetapan metode mengajarkannya agar tujuan yang telah dirumuskan dapat dicapai secara optimal. Salah satu tujuan yang diharapkan akan dicapai dalam pembelajaran bahasa Arab adalah kemampuan membaca atau yang dikenal dengan مهارة القراءة. Tujuan tersebut menentukan strategi dan metode mengajarkan qirä $a h^{22}$

Kemahiran membaca mengandung dua aspek. Adapun aspek-aspek yang terkandung dalam Mahārah al-Qiraāh yaitu:

1. Mengubah lambang tulis menjadi bunyi.

2. Menangkap arti dari pada seluruh situasi yang dilambangkan dengan lambanglambang tulis dan bunyi tersebut. ${ }^{23}$

Inti kemahiran membaca terletak pada aspek yang kedua. Namun tidaklah berarti bahwa kemahiran dalam aspek yang pertama tidak penting. Sebab kemahiran dalam aspek yang pertama mendasari kemahiran yang kedua. Betapapun juga, keduanya merupakan tujuan yang hendak dicapai oleh pengajaran bahasa. Walaupun kegiatan pengajaran membaca dalam pengertian pertama telah diberikan sejak tingkat-tingkat permulaan, namun pembinaannya harus dilakukan juga sampai tingkat

${ }^{20}$ Muhammad Ali Al-Khuli, Asalib Tadris al-Lughah al-Arabiyyah. (Riyadh: al-Mamlakah alArabiyyah al-Su'udiyyah, 1982), h.121.

${ }^{21}$ Anwar Abd Rahman, "Pengajaran Bahasa Arab dengan Metode Eklektik”, Jurnal Adabiyah, Vol. 11 Nomor 1/2011, h. 65.

${ }^{22}$ Marwati, "Metode Pengajaran Qiraah", Jurnal Adabiyah, Vo. 11 Nomor 1/2011, h. 2. Dikases pada http://journal.uin-alauddin.ac.id/index.php/adabiyah/article/view/2115

${ }^{23}$ Abdul Muin, Analisis Kontrastif Bahasa Arab dan Bahasa Indonesia (Telaah terhadap Fonetik dan Morfologi) (Jakarta: Pustaka Al Husna Baru, 2004), h. 171. 
menengah bahkan tingkat lanjutan, melalui kegiatan membaca keras (al-Qira`ah alJahriyah).

Kedua aspek tersebut tidak lain adalah dua kemahiran sekaligus yang tercakup dalam keterampilan membaca. Dua kemahiran yang dimaksud adalah mengenali simbol-simbol tertulis yang ada di dalamnya dan memahami isinya. ${ }^{24}$

Adapun kemampuan yang harus dikembangkan dalam diri pelajar adalah kemahiran mengenai symbol-simbol tertulis yang mencakup penguasaan huruf Arab yang terbagi atas huruf syamsiyyah dan qamariah dengan tanda baca dhammah, fathah, kasrah dan tanwin, syaddah dan tanda-tanda mad termasuk dalam harakah yang berdiri sendiri dan tanda alif panjang, hamzah washl dan hamzah qath $i$. washl dan waqf. ${ }^{25}$

Pelajaran untuk tingkat pemula sebaiknya diberi harakah bagi kata-kata yang baru dikenal sedangkan yang sudah dikenal tidak perlu diberi harakah. Pada prinsipnya, sejak awal para pelajar dilatih dan dibiasakan membaca tanpa harakah dalam rangka membina danmengambangkan kemampuan membaca dan memahami isi. Untuk 'aliyah tingkat akhir pembacaan teks tanpa harakah. Pada latihan kemahiran membaca ini guru juga harus mengembangkan murid terhadap arti atau isi yang dibacanyadalam bahasa Arab sehingga murid merasa senang dan mudah. Ada tiga unsur yang harus diperhatikan dan dikembangkan dalam pelajaran Qira 'ah yaitu kata, kalimat, paragraph. Karena ketiganya berperan sangat penting dalam mendukung makna suatu bahan bacan. Dan untuk mengetahui pemahaman murid tentang sesuatu bacaan, ajukan beberapa pertanyaan tertulis misalnya multiple choice (ikhtiyar al-muta'addid), matching (al-mu 'allamah), fill the blank (mil-u al-faragh), true-fale (shahih aw gholath) dan memberi harakah. ${ }^{26}$

\section{E. Kesimpulan}

Dari pemaparan yang telah pemakalah sajikan dapatlah ditarik kesimpulan bahwasanya:

1. Kemahiran (keterampilan) membaca adalah suatu kemampuan berbahasa yang dimiliki seseorang dalam melihat dan memahami apa makna yang terkandung dalam sebuah tulisan dengan terampil, tepat, dan fasih. Dengan demikian, pesan ingin disampaikan penulis melalui tulisannya dapat ditangkap dan dipahami maknanya oleh si pembaca dengan baik dan tepat.

2. Hal-hal yang perlu diperhatikan oleh seorang guru bahasa Arab dalam pembelajaran Qirāa $a h$ untuk menciptakan keterampilan berbahasa dalam hal ini Maharah al-qirā'ah dengan baik, mudah dan tepat sasaran, adalah:

${ }^{24}$ Ahmad Izzan, op. cit., h. 174. Bandingkan: Tim Penyusun, Pedoman Pengajaran Bahasa Arab pada Perguruan Tinggi Agama Islam (Jakarta: Proyek Pengembangan Sistem Pendidikan Agama Departemen Agama, 1976), h. 168.

${ }^{25}$ Ahmad Izzan, Ibid., h .175-176.

${ }^{26}$ Ibid., h. 177. 

a. Tujuan pembelajaran qirā'ah
b. Strategi pembelajaran qirā'ah
c. Media pembelajaran qirā ${ }^{\prime} a h$
d. Metode pembelajaran qirā'ah

3. Kemampuan yang harus dikembangkan dalam diri pelajar adalah kemahiran mengenai simbol-simbol tertulis. Ada tiga unsur yang harus diperhatikan dan dikembangkan dalam pelajaran qira ‘h yaitu kata, kalimat, paragrap. Ketiganya berperan sangat penting dalam mendukung makna suatu bahan bacan, dan untuk mengetahui pemahaman murid tentang sesuatu bacaan

\section{Daftar Pustaka}

Arsyad, Azhar. Bahasa Arab dan Metode Pengajarannya: Beberapa Pokok Pikiran Cet. II ; Jakarta : Pustaka Pelajar , 2004.

Fahmi, AH. Akrom Ilmu Nahwu dan Sharaf (Tata Bahasa Arab) Praktis dan Aplikatif . Cet. I II ; Jakarta : PT. Raja Grafindo, 2003.

Gala, Syaiful. Konsep dan Makna Pembelajaran . Bandung: Alfabeta, 2005.

Hafizh, Mahmud Faraj. Abd. dkk, Muzakkirat al-Dirasah al-Tarbawiyah. t.c; t.tp: $1412 \mathrm{H}$.

Http:// Ahsan Blogdetik. Com/2008/12/28/Pemamfaatan Internet dalam Pembelajaran Bahasa Arab ( 25 Maret 2009).

Izzan, Ahmad. Metodologi Pembelajaran Bahasa Arab (Cet. I; Bandung: Humaniora, 2004.

Al-Khuli, Muhammad Ali. Asalib Tadris al-Lughah al-Arabiyyah. (Riyadh: alMamlakah al-Arabiyyah al-Su'udiyyah, 1982

Ma'ruf, Nāyif Mahmud. Khasāis\} al-'Arabiyyah wa Tārāiq Tadrisiha (Cet. IV; Beirut-Libnan: Dār al-Nafais, 1412 H/1991 M.), h. 88-90.

Makruf, Imam. Strategi Pembelajaran Bahasa Arab Aktif (Cet. I; Semarang: 2009)

Malibary A. Akrom. L.A.S. et. al. Pedoman Pengajaran Bahasa Arab pada Perguruan Tinggi Agama Islam. Jakarta: Proyek Pengembangan Sistim Pendidikan Agama Depag RI, 1976.

Marwati, “Metode Pengajaran Qiraah”, Jurnal Adabiyah, Vo. 11 Nomor 1/2011.

Mu`in, Abdul. Analisis Kontrastif Bahasa Arab dan Bahasa Indonesia (Telaah terhadap Fonetik dan Morfologi). Jakarta: Pustaka Al Husna Baru, 2004. 
Munawwir, Ahmad Warson. Al-Munawwir:Kamus Arab-Indonesia. Surabaya: Pustaka Progresif, 1997.

Abd Rahman, Anwar. "Pengajaran Bahasa Arab dengan Metode Eklektik", Jurnal Adabiyah, Vol. 11 Nomor 1/2011

Salim, Ahmad. al-Wasâîl al-Ta liymiyyah fi Ta liym al-Lughah, Jakarta: t.p.,1987.

Tarigan, Henry Guntur. Membaca ; Sebagai Suatu Keterampilan Berbahasa, Ed, Revisi. Cet. I; Bandung: Angkasa Bandung, 2008.

Tim Penyusun, Pedoman Pengajaran Bahasa Arab pada Perguruan Tinggi Agama Islam. Jakarta: Proyek Pengembangan Sistem Pendidikan Agama Departemen Agama, 1976 